\title{
MODERATE INTENSITY PHYSICAL EXERCISE: PSYCHONEUROIMMUNOLOGICAL ASPECTS
}

EXERCÍCIO FÍSICO DE INTENSIDADEMODERADA: ASPECTOS PSICONEUROIMUNOLÓGICOS

EJERCICIO FÍSICO DE INTENSIDAD MODERADA: ASPECTOS PSICONEUROINMUNOLÓGICOS
Review Articles

ARTIGOS DE REVISÃo ARtículos de REVISIÓN
Eduardo Vignoto Fernandes (Physical Education Professional) Celio Estanislau² (Psychologist)

Emerson José Venancio ${ }^{3}$ (Biologist)

\section{Universidade Estadual de Londrina (UEL), Department of Anatomy, Londrina, PR, Brazil. 2. Universidade Estadual de Londrina (UEL), Department of General Psychology and Behavior Analysis, Behavior Analysis Graduate Degree Program and Post-Graduate Program in Health Sciences, Londrina, PR, Brazil. 3. Universidade Estadual de Londrina (UEL), Department of Pathological Sciences, Experimental Pathology Graduate Degree Program and Clinical and Laboratorial Pathophysiology Graduate Degree Program, Londrina, PR, Brazil.}

\section{Correspondence:}

Emerson José Venancio.

Department of Pathological Sciences/UEL.

Rodovia Celso Garcia Cid (PR-445), KM 380, Campus Universitário, Londrina, PR, Brazil. 86057-970. emersonj@uel.br

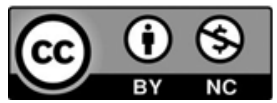

\begin{abstract}
The literature presents several instances of interaction between the nervous system (NS) and the immune system (IS). These interactions are promoted by several molecules, such as cytokines and hormones, with modulating action for both the NS and IS. In this sense, the two systems may influence each other: changes in behavior may be accompanied by alterations in the IS (e.g., immunosuppression) and immunological disorders, such as infections, may modulate behavior (e.g., anxiety and depression). Considering that chronic stress, in addition to affecting behavior, also modulates the IS and that there is evidence that moderate intensity physical exercise (PE) protects physical and mental health, the objective of this review is to explore the influence of moderate-intensity PE on behavior and immunity. Level of Evidence $V$; Expert opinion.
\end{abstract}

Keywords: Immunomodulation; Immune system; Behavior.

\section{RESUMO}

A literatura apresenta diversas instâncias de interação entre o sistema nervoso (SN) e o sistema imunológico (SI). Essas interações são promovidas por diversas moléculas, como citocinas e hormônios com ação moduladora tanto para o SN quanto o SI. Nesse sentido, os dois sistemas podem ter influência mútua: as alterações do comportamento podem ser acompanhadas por alterações do SI (por exemplo, imunossupressão), e distúrbios imunológicos como infecções, podem modular o comportamento (por exemplo, ansiedade e depressão). Considerando que o estresse crônico, além de afetar o comportamento, modula o Sl e que há evidências de que o exercício físico (EF) de intensidade moderada ajuda a proteger a saúde física e mental, o objetivo da presente revisão é explorar a influência do EF de intensidade moderada sobre o comportamento e a imunidade. Nível de Evidência V; Opinião do especialista.

Descritores: Imunomodulação; Sistema imunológico; Comportamento.

\section{RESUMEN}

La literatura presenta diversas instancias de interacción entre el sistema nervioso (SN) y el sistema inmune (SI). Estas interacciones son promovidas por diversas moléculas, como citosinas y hormonas, con acción moduladora tanto para el SN como para el SI. En este sentido, los dos sistemas pueden influenciarse mutuamente: los cambios en el comportamiento pueden ser acompañados por alteraciones en el SI (inmunosupresión) y los disturbios inmunológicos, como infecciones, pueden modular el comportamiento (ej. ansiedad y depresión). Considerando que el estrés crónico, además de impactar el comportamiento, también modula el Sl y que hay evidencias de que el ejercicio físico (EF) de intensidad moderada es un protector para la salud física y mental, el objetivo de la presente revisión es explotar la influencia del EF de intensidad moderada en el comportamiento y la inmunidad. Nivel de Evidencia V; Opinión del especialista.

Descriptores: Inmunomodulación; Sistema Inmunológico; Conducta.

\section{INTRODUCTION}

Stress, which may occur acutely or chronically, is a frequent phenomenon in society. ${ }^{1}$ Both forms are related to stressors that affect people at all times, for example, in traffic, at work, or in their family life. ${ }^{2}$ Therefore, it has been observed that the number of people under stress is large, varying from 18 to $65 \%$ depending on the country or demographics., ${ }^{3,4}$

Epidemiological data show that stress in its chronic form significantly alters behavior and may lead to mood disorders and, especially, depression. ${ }^{2}$ In fact, stress can deregulate the hypothalamic-pituitaryadrenal (HPA) axis; increase the recapture and degradation of serotonin; increase degradation of tryptophan; and reduce production of BrainDerivedNeurotrophic Factor (BDNF)..$^{5-7}$ In addition, chronic stress can promote immunosuppression, affecting cells and lymphoid organs, altering the production of antibodies and cytokines, as a result of an imbalance in the activation ofTh1/Th2 cells..$^{8-10}$ This is because, chronic stress, by deregulating the HPA axis, maintains high levels of circulating cortisol. As cells of the immune system (IS) have receptors for cortisol, the activation of these receptors inhibits the production of inflammatory cytokines such as interleukin-1-beta (IL-1 $\beta$ ), interleukin-6 (IL-6), and tumor necrosis factor-alpha (TNF- $a){ }_{1}^{11,12}$ causing less effectiveness of the organism in the fight against infectious diseases and an increase in the time taken forwound healing. ${ }^{13}$ This imbalance in the immune system, caused by chronic stress, has a strong association with the development of depression in clinical and experimental studies..$^{14,15}$ 
Unlike chronic stress, moderate intensity physical exercise (PE), when practiced regularly, has an anti-inflammatory and immunostimulatory action, and reduces the signs and symptoms of stress. ${ }^{6,7,16,17}$ Animal studies, for example, provide evidence that moderate PE can ameliorate some of the effects of stress. Regarding behavior, Sprague-Dawley rats submitted to moderate-intensity PE presented behavioral alterations compatible with a reduction in stress levels and increased BDNF mRNA expression. ${ }^{6}$ A reduction in passive behavior when faced with aversive situations was also observed in mice submitted to 14 days of voluntary running. ${ }^{17}$ Moderate intensity PE was shown to have an anti-inflammatory action, changing the pattern of cellular immune response to humoral response in rats. ${ }^{16}$ In addition, PE was able to reduce serum cortisol levels, stimulating neuroplasticity and serotonin production. ${ }^{6,7}$ In humans, it was observed that moderate intensity PE provided cognitive improvement in depressive volunteers. ${ }^{18}$ In elderly women, regular practice of moderate intensity PE stimulated the production of specific anti-influenza antibodies (IgM and lgG) compared to a group of sedentary women. ${ }^{19}$ In men diagnosed with prostate cancer, it was observed that moderate intensity PE during treatment decreased the production of inflammatory markers and fatigue. ${ }^{20}$ Another study showed that moderate PE reduced inflammation in women with Systemic Lupus Erythematosus. ${ }^{21}$ Thus, the purpose of this review is to explore the role of moderate intensity PE in relation to psychoneuroimmunological aspects.

\section{Communication between the nervous system and the immune system}

When an individual is affected by stressful situations, their organism presents physiological alterations that leave them in a state of alert (e.g., minutes before a competition), remaining in this state until the end of the action. ${ }^{5}$ At this moment, certain hormones increase such as cortisol, adrenaline, and noradrenaline. As a result, there is an increase in respiratory rate, heart rate, blood glucose concentration, and blood flow to the skeletal muscles. ${ }^{22}$ Through this rapid change in behavior, stress is related to the survival of the individual, also known as the fight or flight response. ${ }^{5}$

In addition, when the individual is affected by long periods of stress, an imbalance occurs in the negative feedback of the HPA axis and elevated cortisol levels are found in the circulation, decreasing the number of receptors involved with the negative feedback and, thus, increasing amounts of cortisol are released into circulation. ${ }^{5}$ Cortisol regulates neuronal survival, excitability, and neurogenesis through the activation of glucocorticoid receptors responsible for inhibiting the expression of neurotrophic factors, such as BDNF. The reduction in the expression of these factors implies in the death of neural cells and in lower hippocampal neurogenesis, conditions associated with the appearance of depressive symptoms. ${ }^{23,24}$

This imbalance in serum cortisol levels also influences the IS, through a set of molecules, cells, tissues, and organs that function collectively to provide immunity, or protection, against external pathogens. ${ }^{25}$ This is because IS cells also present receptors for cortisol. The activation of these receptors by cortisol inhibits the production of inflammatory cytokines such as IL-1 $\beta, I L-6$, and TNF- $a,{ }^{11,12}$ reducing the effectiveness of the organism in combating infectious diseases and increasing the time taken for wound healing. ${ }^{13}$

Animal studies also present evidence that chronic stress suppresses the IS. ${ }^{8,9}$ Mice subjected to chronic stress present a compromised immune system, as observed by the reduction in cell proliferation and production of pro-inflammatory cytokines (TCD4+ lymphocytes, interferon-gamma $($ INF- $\gamma$ ), and TNF-a). These alterations lead to a decrease in the survival of these animals. ${ }^{8}$ Furthermore, rats submitted to inescapable shock stress suppress the production of antibodies: immunoglobulin M (IgM) and immunoglobulinG2a (lgG2a). ${ }^{9}$

Acute stress, in turn, is recognized by immunoprotection (Figure 1). This is because in an alert situation (fight or flight), acute stress prepares the IS for alterations (injury or infection) that may occur through confrontations (e.g., predator attack). ${ }^{26}$ As an example, acute restraint stress activated mast cells in Wistar rats. ${ }^{27}$ In humans, acute stress increased serum levels of $1 \mathrm{~L}-6^{28}$ and increased the activity and number of Natural Killer cells in peripheral blood. ${ }^{29}$

The IS can regulate the nervous system (NS) by means of cytokines. This has been observed through increased production of proinflammatory cytokines, especially IL-1 $\beta$, IL-6, and TNF-a, which can be produced by either immune or non-immune cells. These cytokines play a key role in the communication between the NS and IS, for example, IL 1- $\beta$ influences the HPA axis by stimulating the hypothalamus to produce corticotropin-releasing hormone $(\mathrm{CRH})$, a molecule responsible for stimulating the production of adrenocorticotropic hormone (ACTH) by the pituitary gland. ${ }^{30}$ In the case of the IL-6 and TNF-a cytokines, when recognized by the pituitary gland, stimulate the production of $\mathrm{ACTH}$, a molecule that communicates with the adrenal gland cortex, stimulating the production of cortisol. ${ }^{30}$ Thus, the increase in stress hormones due to the action of cytokines suggests that the IS may be implicated in depression.

In this sense, one possibility is that behavioral disorders with inflammatory origin should not be treated with antidepressant medications but rather with anti-inflammatory drugs. ${ }^{30}$ In addition, the literature has pointed out that non-pharmacological measures such as the practice of PE are also effective in controlling behavioral disorders and in the regulation of the $\mathrm{IS}^{31,32}$

\section{Moderate intensity physical exercise regulating behaviour}

Research with humans and animals supports a positive action of physical exercise (PE) on the physiological and behavioral alterations caused by chronic stress, being increasingly accepted as an intervention that can reduce signs and symptoms of cognitive dysfunctions and behavioral disorders such as depression and anxiety. 6,17,32,33 This efficiency of PE to improve cognitive and behavioral parameters has been compared to pharmacological treatments and psychological interventions. ${ }^{34}$ However,

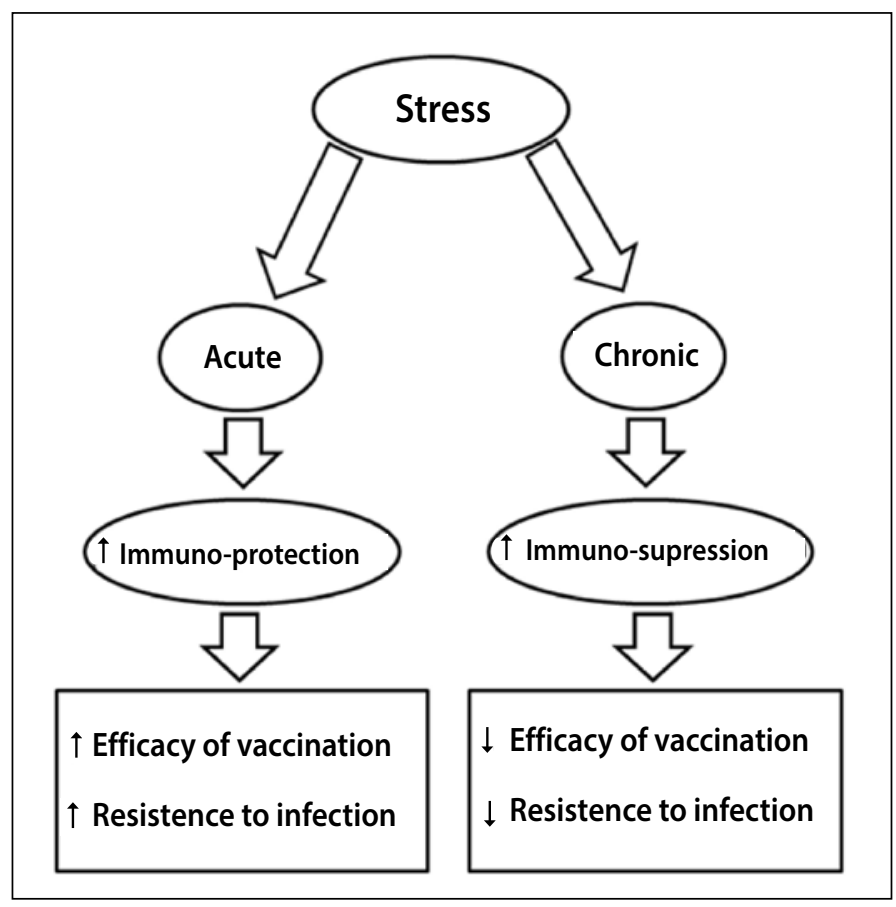

Figure 1. Effect of acute and chronic stress on the SI. Adapted from Dhabhar ${ }^{26}$. 
although physically active individuals exhibit fewer health problems, even when faced with stressful situations, which can be verified by the normalization of serum levels of cortisol and serotonin, molecules that are altered in individuals under stress, the ideal amount and type of exercise for maximum protection are not yet known. ${ }^{35}$

In contrast, moderate intensity PE is known to prevent the suppressive effects of stress on BDNF expression, hippocampal neurogenesis, synaptic plasticity, and neural survival. ${ }^{36,37}$ An example of this was observed in Sprague-Dawley rats submitted concomitantly to stress and PE. ${ }^{6}$ In this study, the effects of stress were, at least in part, prevented by PE, being observed in behavioral tests (preference for sucrose and open field) and by the increase in BDNF mRNA expression. ${ }^{6}$ The ability of PE to prevent the effects of stress suggests its potential for the control of depression.

In fact, different studies have demonstrated the usefulness of PE in the intervention and control of diseases, such as depression and panic disorder..$^{38-40}$ In this way, Plag et al. ${ }^{40}$, analyzing the effects of moderate intensity PE on the concentration of salivary cortisol in individuals with panic disorder, observed that after seven months of PE the individuals presented a reduction in salivary cortisol levels when compared to non-exercised subjects. In patients with insomnia, it was also observed that the practice of moderate intensity PE for 4 months improved sleep quality and reduced serum cortisol levels. ${ }^{41}$ Other studies have shown that PE is also effective in treating stress for both normal-weight ${ }^{39}$ and obese individuals. ${ }^{38}$ Given this context, the importance of performing PE in order to prevent or attenuate behavioral alterations is clear.

\section{Moderate intensity physical exercise regulating the immune system}

Moderate intensity PE has beneficial effects on the IS, such as greater protection against infections, an increase in the effectiveness of vaccines, and an increase in the proportion of differentiated T cells in circulation. 19,42,43

Within this context, research evaluating the effects of PE on the IS has increased in recent years. $42,4,45$ The first investigations that related the intervention of PE in the IS began in the late sixties. During this period, the emphasis was on whether PE could influence the number of secreted proteins in the urine, e.g., immunoglobulins, after exercise. ${ }^{46}$ Since then, research has been carried out to elucidate how PE can modulate the IS. ${ }^{44,45}$

The immunomodulatory effect of PE has been observed in experimental studies with animals and humans. ${ }^{47,48}$ This immunomodulation is dependent on the intensity of the effort, so that moderate intensity PE is known to facilitate positive adaptations to the IS ${ }^{43,49}$ independently of whether it is carried out acutely or chronically. ${ }^{45}$

The cytokine patterns produced by Thelper (Th) lymphocytes are influenced by PE. ${ }^{50-52}$ There are different subpopulations of Th lymphocytes; the two most commonly studied are Thelper type 1 (Th1) and Thelper type 2 (Th2) lymphocytes. Th1 lymphocytes are essential in cell-mediated immune response in defense against intracellular pathogens as well as producing proinflammatory cytokines such as interferon-gamma (IFN- $\gamma$ ) and interleukin-2 (IL-2). Th2 lymphocytes, on the other hand, produce anti-inflammatory cytokines such as interleukin-4 (IL-4), interleukin-5 (IL-5), interleukin-10 (IL-10), and interleukin-13 (IL-13), being responsible for host defense against parasites and other extracellular pathogens. In addition, Th1 pattern cytokines, e.g., INF-y, suppress the production of Th2 pattern cytokines such as IL-4, which suppress the production of Th1 pattern cytokines. . $^{50,52}$

The immunomodulation exerted on the IS by moderate intensity PE is, at least in part, dependent on the IL-6 produced by the muscle. ${ }^{3,54}$ Unlike the inflammatory process, which stimulates the production of IL-6 by mononuclear cells via NF-kB, moderate-intensity physical exercise stimulates the production of IL-6 in the uninjured muscle via p38
MAPK and/or Calcineurin-NFAT. The phosphorylation of these molecules activates transcription factors (CREBP, p300, CBP, NFAT, and AP-1) that act in the production of IL-6, independent of the NF-KB pathway which is not activated by muscle contraction. ${ }^{53}$ The IL- 6 produced by the muscle has an anti-inflammatory action, stimulating the production of IL-10 and cortisol and inhibiting the production of TNF-a, in order to favor the Th2 response pattern. ${ }^{54,55}$

Animal studies illustrate how moderate PE can exert effects through IL-6 production. For example, this was observed in mice infected with Streptococcus pneumoniae 72 hours after being submitted to a protocol of moderate intensity PE for 4 weeks, in which the PE attenuated the bacterial growth and inflammatory process in the lung when compared to control animals. ${ }^{47}$ These findings are supported by the fact that moderate intensity PE favors the production of IL-6 by the muscle via MAPK and has an antioxidant effect. ${ }^{53,54,56} \mathrm{In}$ another study, mice submitted to a moderate intensity PE protocol initiated after infection with the influenza virus presented lower numbers of infiltrated cells in the lung and reduced viral load. ${ }^{51}$

In vaccinated individuals, moderate intensity PE is known to increase the migration of lymphocytes to the site of administration of the vaccine through increased recognition and processing of the antigen; a greater number of monocytes and circulating dendritic cells; and increased migration of the cells that are in the sites of the antigen to the lymphoid nodules, a condition that favors the production of antibodies 45 (Figure 2). As an example, elderly women participating in a PE program for 12 months produced higher levels of anti-influenza (IgM and IgG) antibodies compared to sedentary women. ${ }^{19}$ Another study showed that elderly subjects who performed 10 months of PE (25 to 30 minutes/ day, 3 times/week) also demonstrated higher production of antibodies against influenza due to the $P E .{ }^{57}$ In addition to the influenza vaccine, moderate intensity PE was also effective in potentiating the effects of the pneumococcal vaccine. Young adults immunized with the pneumococcal vaccine, after 15 minutes of moderate PE, demonstrated higher antibody production when compared to the non-exercised individuals. ${ }^{42}$

As moderate intensity PE has a positive role on the immune system, studies have highlighted several ways of applying it as a non-pharmacological intervention measure for the treatment $\mathrm{t}^{48}$ and prevention ${ }^{58}$ of diseases. As an example, moderate intensity PE reduced abnormally high levels of some cytokines (INF-y, IL-10, IL-6, and TNF-a) in women with Systemic Lupus Erythematosus. ${ }^{48}$ Another study demonstrated that women with breast cancer can benefit from PE in order to reduce the body fatigue caused by the disease, thus also improving the quality of life of patients..$^{59}$ In this sense, the importance of the practice of moderate intensity PE in the immunomodulation of the IS is evident.

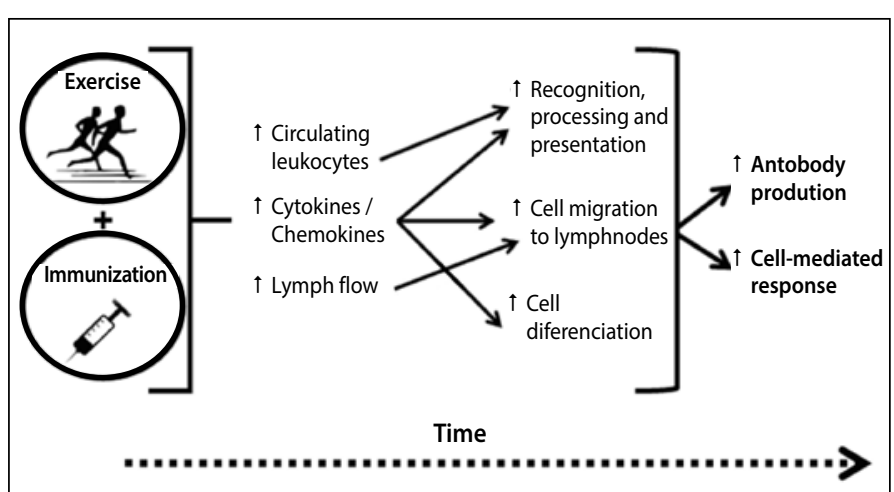

Figure 2. Effect of moderate intensity PE promoting the production of antibodies. Adapted from Pascoe et al. ${ }^{45}$ 


\section{CONCLUSION}

With this review we can conclude that cortisol is the important molecule for altering both behavior and the immune system. This is because, cortisol, when chronically elevated in the circulation, besides changing behavior is also an immunosuppressive.

Regarding the IS, it was observed that its exacerbated activation increases the production of proinflammatory cytokines, which bind in certain regions of the HPA axis, deregulating it and stimulating unwanted production of cortisol.
On the other hand, moderate intensity physical exercise has been shown to be an important tool in the management of behavioral disorders and the immune system, evidenced by regulation of the HPA axis and production of anti-inflammatory cytokines by muscle cells.

All authors declare no potential conflict of interest related to this article.

AUTHORS' CONTRIBUTIONS: Each author contributed individually and significantly to the development of the manuscript, performing the writing, review, and intellectual concept of the article. EVF (0000-0003-0876-2491)*, CE (0000-0003-4630-3317)*, EJV (0000-0002-3735-9207)*. *ORCID (Open Researcher and Contributor ID).

\section{REFERENCES}

1. Stein DJ, Chiu WT, Hwang I, Kessler RC, Sampson N, Alonso J, et al. Cross-national analysis of the associations between traumatic events and suicidal behavior: findings from the WHO World Mental Health Surveys. PLoS One. 2010;5(5):e10574.

2. Barlow DH, Durand VM. Abnormal Psychology: An Integrative Approach, 7th ed. Stamford:Cengage learning, 2015.

3. Sahoo S, Khess CR. Prevalence of depression, anxiety, and stress among young male adults in India: a dimensional and categorical diagnoses-based study. J Nerv Ment Dis. 2010;198(12):901-4.

4. Sbaraini CR, Schermann LB. Prevalence of childhood stress and associated factors: a study of schoolchildren in a city in Rio Grande do Sul State, Brazil. Cad Saude Publica. 2008;24(5):1082-8.

5. Herman JP, MCKlveen JM, Solomon MB, Carvalho-Netto E, Myers B. Neural regulation of the stress response: glucocorticoid feedback mechanisms. Braz J Med Biol Res. 2012;45(4):292-8.

6. Jiang P, Dang RL, Li HD, Zhang LH, Zhu WY, Xue Y, et al. The impacts of swimming exercise on hippocampal expression of neurotrophic factors in rats exposed to chronic unpredictable mild stress. Evid Based Complement Alternat Med. 2014;2014.

7. Liu W, Sheng H, Xu Y, Liu Y, Lu J, Ni X. Swimming exercise ameliorates depression-like behavior in chronically stressed rats: relevant to proinflammatory cytokines and IDO activation. Behav Brain Res. 2013;242:110-6.

8. Frick LR, Arcos ML, Rapanelli M, Zappia MP, Brocco M, Mongini C, et al. Chronic restraint stress impairs T-cell immunity and promotes tumor progression in mice. Stress. 2009;12(2):134-43.

9. Kennedy SL, Nickerson M, Campisi J, Johnson JD, Smith TP, Sharkey C, et al. Splenic norepinephrine depletion following acute stress suppresses in vivo antibody response. J Neuroimmunol. 2005;165(1-2):150-60

10. Vignjevic S, Budec M, Markovic D, Dikic D, Mitrovic O, Diklic M, et al. Glucocorticoid receptor mediates the expansion of splenic late erythroid progenitors during chronic psychological stress. J Physiol Pharmacol. 2015;66(1):91-100.

11. Hodes GE, Kana V, Menard C, Merad M, Russo SJ. Neuroimmune mechanisms of depression. Nat Neurosci. 2015;18(10):1386-93.

12. Segerstrom SC, Miller GE. Psychological stress and the human immune system: a meta-analytic study of 30 years of inquiry. Psychol Bull. 2004;130(4):601-30.

13. Robles TF, Glaser R, Kiecolt-Glaser JK. A New Look at Chronic Stress, Depression, and Immunity. Curr Dir Psychol Sci. 2005;14(2):111-5

14. Fuertig R, Azzinnari D, Bergamini G, Cathomas F, Sigrist H, Seifritz E, et al. Mouse chronic social stress increases blood and brain kynurenine pathway activity and fear behaviour: Both effects are reversed by inhibition of indoleamine 2,3-dioxygenase. Brain Behav Immun. 2016;54:59-72.

15. Rawdin BJ, Mellon SH, Dhabhar FS, Epel ES, Puterman E, Su Y, et al. Dysregulated relationship of inflammation and oxidative stress in major depression. Brain Behav Immun. 2013;31:143-52.

16. Wasinski F, Gregnani MF, Ornellas FH, Bacurau AV, Câmara NO, Araujo RC, et al. Lymphocyte glucose and glutamine metabolism as targets of the anti-inflammatory and immunomodulatory effects of exercise. Mediators Inflamm. 2014;2014.

17. Yau SY, Li A, Hoo RL, Ching YP, Christie BR, Lee TM, et al. Physical exercise-induced hippocampal neurogenesis and antidepressant effects are mediated by the adipocyte hormone adiponectin Proc Natl Acad Sci U S A. 2014;111(44):15810-5.

18. Sadeghi K, Ahmadi SM, Moghadam AP, Parvizifard A. The Study of Cognitive Change Process on Depression during Aerobic Exercises. J Clin Diagn Res. 2017;11(4):IC01-5.

19. Bachi AL, Suguri VM, Ramos LR, Mariano M, Vaisberg M, Lopes JD. Increased production of autoantibodies and specific antibodies in response to influenza virus vaccination in physically active older individuals. Results Immunol. 2013:3:10-6.

20. Hojan K, Kwiatkowska-Borowczyk E, Leporowska E, Górecki M, Ozga-Majchrzak O, Milecki T, et al. Physical exercise for functional capacity, blood immune function, fatigue, and quality of life in high-risk prostate cancer patients during radiotherapy: a prospective, randomized clinical study. Eur J Phys Rehabil Med. 2016;52(4):489-501.

21. Perandini LA, Sales-de-Oliveira D, Mello S, Camara NO, Benatti FB, Lima FR, et al. Inflammatory cytokine kinetics to single bouts of acute moderate and intense aerobic exercise in women with active and inactive systemic lupus erythematosus. Exerc Immunol Rev. 2015;21:174-85.

22. Kvetnansky R, Lu X, Ziegler MG. Stress-triggered changes in peripheral catecholaminergic systems. Adv Pharmacol. 2013;68:359-97.

23. Anacker C, Zunszain PA, Carvalho LA, Pariante CM. The glucocorticoid receptor: pivot of depression and of antidepressant treatment? Psychoneuroendocrinology. 2011;36(3):415-25.

24. Warner-Schmidt JL, Duman RS. Hippocampal neurogenesis: opposing effects of stress and antidepressant treatment. Hippocampus. 2006;16(3):239-49.

25. Terra R, da Silva SAG, Pinto VS, Dutra PML. Effect of exercise on the immune system: response, adaptation and cell signaling. Rev Bras Med Esporte. 2012;18(3):208-14.

26. Dhabhar FS. Effects of stress on immune function: the good, the bad, and the beautiful. Immunol Res. 2014:58(2-3):193-210.

27. Căruntu C, Boda D, Musat S, Căruntu A, Mandache E. Stress-induced mast cell activation in glabrous and hairy skin. Mediators Inflamm. 2014;2014.

28. Griffis CA, Breen EC, Compton P, Goldberg A, Witarama T, Kotlerman J, et al. Acute painful stress and inflammatory mediator production. Neuroimmunomodulation. 2013;20(3):127-33.

29. van Venrooij JA, Fluitman SB, Lijmer JG, Kavelaars A, Heijnen CJ, Westenberg HG, et al. Impaired neuroendocrine and immune response to acute stress in medication-naive patients with a first episode of psychosis. Schizophr Bull. 2012;38(2):272-9.
30. Gądek-Michalska A, Tadeusz J, Rachwalska P, Bugajski J. Cytokines, prostaglandins and nitric oxide in the regulation of stress-response systems. Pharmacol Rep. 2013;65(6):1655-62.

31. Schuch FB. Progress in the study of the effects of exercise on affective and anxiety disorders. Front Psychiatry. 2014;5:153.

32. Tuon T, Valvassori SS, Dal Pont GC, Paganini CS, Pozzi BG, Luciano TF, et al. Physical training prevents depressive symptoms and a decrease in brain-derived neurotrophic factor in Parkinson's disease. Brain Res Bull. 2014;108:106-12.

33. Marques AH, Bjørke-Monsen AL, Teixeira AL, Silverman MN. Maternal stress, nutrition and physical activity: Impact on immune function, CNS development and psychopathology. Brain Res. 2015;1617:28-46.

34. Rethorst CD, Wipfli BM, Landers DM. The antidepressive effects of exercise: a meta-analysis of randomized trials. Sports Med. 2009;39(6):491-511

35. He SB, Tang WG, Tang WJ, Kao XL, Zhang CG, Wong XT. Exercise intervention may prevent depression Int J Sports Med. 2012;33(7):525-30.

36. Ieraci A, Mallei A, Musazzi L, Popoli M. Physical exercise and acute restraint stress differentially modulate hippocampal brain-derived neurotrophic factor transcripts and epigenetic mechanisms in mice. Hippocampus. 2015;25(11):1380-92.

37. Schoenfeld TJ, Rada P, Pieruzzini PR, Hsueh B, Gould E. Physical exercise prevents stress-induced activation of granule neurons and enhances local inhibitory mechanisms in the dentate gyrus. Neurosci. 2013;33(18):7770-7.

38. Brumby S, Chandrasekara A, Kremer P, Torres S, McCoombe S, Lewandowski P. The effect of physical activity on psychological distress, cortisol and obesity: results of the Farming Fit intervention program. BMC Public Health. 2013;13(18):1018.

39. Klaperski S, von Dawans B, Heinrichs M, Fuchs R. Effects of a 12-week endurance training program on the physiological response to psychosocial stress in men: a randomized controlled trial. J Behav Med. 2014;37(6):1118-33.

40. Plag J, Gaudlitz K, Schumacher S, Dimeo F, Bobbert T, Kirschbaum C, et al. Effect of combined cognitive-behavioural therapy and endurance training on cortisol and salivary alpha-amylase in panic disorder. J Psychiatr Res. 2014;58:12-9.

41. Passos GS, Poyares D, Santana MG, Teixeira AA, Lira FS, Youngstedt SD, et al. Exercise improves immune function, antidepressive response, and sleep quality in patients with chronic primary insomnia. Biomed Res Int. 2014;2014.

42. Edwards KM, Pung MA, Tomfohr LM, Ziegler MG, Campbell JP, Drayson MT, et al. Acute exercise enhancement of pneumococcal vaccination response: a randomised controlled trial of weaker and stronger immune response. Vaccine. 2012;30(45):6389-95.

43. Simpson RJ, Bosch JA. Special issue on exercise immunology: current perspectives on aging, health and extreme performance. Brain Behav Immun. 2014;39:1-7.

44. Krüger K, Mooren FC. Exercise-induced leukocyte apoptosis. Exerc Immunol Rev. 2014:20:117-34 45. Pascoe AR, Fiatarone Singh MA, Edwards KM. The effects of exercise on vaccination responses: review of chronic and acute exercise interventions in humans. Brain Behav Immun. 2014;39:33-41.

46. Poortmans J, Jeanloz RW. Quantitative immunological determination of 12 plasma proteins excreted in human urine collected before and after exercise. J Clin Invest. 1968;47(2):386-93.

47. Olivo CR, Miyaji EN, Oliveira ML, Almeida FM, Lourenço JD, Abreu RM, et al. Aerobic exercise attenuates pulmonary inflammation induced by Streptococcus pneumoniae. J Appl Physiol (1985) 2014;117(9):998-1007.

48. Perandini LA, Sales-de-Oliveira D, Mello SB, Camara NO, Benatti FB, Lima FR, et al. Exercise training can attenuate the inflammatory milieu in women with systemic lupus erythematosus. J Appl Physiol (1985). 2014;117(6):639-47.

49. Mackinnon LT. Chronic exercise training effects on immune function. Med Sci Sports Exerc. 2000;32(7 Suppl):S369-76.

50. Gholamnezhad Z, Boskabady MH, Hosseini M, Sankian M, Rad AK. Evaluation of immune response after moderate and overtraining exercise in wistar rat. Iran J Basic Med Sci. 2014;17(1):1-8.

51. Lowder T, Padgett DA, Woods JA. Moderate exercise early after influenza virus infection reduces the Th1 inflammatory response in lungs of mice. Exerc Immunol Rev. 2006;12:97-111.

52. Zhao G, Zhou S, Davie A, Su Q. Effects of moderate and high intensity exercise on T1/T2 balance. Exerc Immunol Rev. 2012;18:98-114

53. Pedersen BK, Febbraio MA. Muscle as an endocrine organ: focus on muscle-derived interleukin-6. Physiol Rev. 2008;88(4):1379-406.

54. Reihmane D, Dela F. Interleukin-6: possible biological roles during exercise. Eur J Sport Sci. 2014;14(3):242-50

55. Woods JA, Vieira VJ, Keylock KT. Exercise, inflammation, and innate immunity. Neurol Clin. 2006;24(3):585-99.

56. Lima TI, Monteiro IC, Valença S, Leal-Cardoso JH, Fortunato RS, Carvalho DP, et al. Effect of exercise training on liver antioxidant enzymes in STZ-diabetic rats. Life Sci. 2015;128:64-71.

57. Kohut ML, Arntson BA, Lee W, Rozeboom K, Yoon KJ, Cunnick JE, et al. Moderate exercise improves antibody response to influenza immunization in older adults. Vaccine. 2004;22(17-18):2298-306.

58. Dias R, Baganha RJ, Cieslak F, Krinski K, Camarço NF, Verlengia R, et al. Immunological parameters and upper respiratory tract infections in team sports athletes. Rev Bras Med Esporte. 2017;23(1):66-72.

59. Meneses-Echávez JF, González-Jiménez E, Ramírez-Vélez R. Effects of supervised exercise on cancerrelated fatigue in breast cancer survivors: a systematic review and meta-analysis. BMC Cancer. 2015;15:77 